\title{
Peer Assessment within Hybrid and Online Courses: Students' View of Its Potential and Performance
}

\author{
Daniel Sullivan \\ Lerner College of Business and Economics \\ University of Delaware, Newark, DE 19716, USA \\ Tel: 1-302-831-4566_E-mail: dps@udel.edu \\ Sharon Watson (Corresponding author) \\ Lerner College of Business and Economics \\ University of Delaware, Newark, DE 19716, USA \\ Tel: 1-302-831-4560Ｅ-mail: watsons@udel.edu
}

Received: March 15, 2015 Accepted: April 10, 2015 Published: April 15, 2015

doi:10.5296/jei.vli1.7255 URL: http://dx.doi.org/10.5296/jei.vli1.7255

\begin{abstract}
The scale and scope of online education increasingly expand. In tandem, interest grows among educators and scholars in understanding the personal and contextual factors that moderate the efficient design and effective delivery of an online course. This paper looks at a theoretically robust method, peer assessment administered by the Canvas learning management system, and evaluates its potential and performance in university-level hybrid and online courses. Cross-sectional data profile students' views, both prior to as well as post-experience, of aspects of the peer review process. Frequency analyses, mean comparisons, and t-tests highlight students' initial strong, positive agreement with the potential but then, post-experience, weaker support of the value of peer assessment. Controlling for time and place, in terms of hybrid versus online sections, did not moderate this outcome. Collectively, these results call for refining our interpretation of the utility of peer assessment to promoting student engagement. We evaluate the moderating influence of anonymity and the social dynamic of self-directed learning, particularly given the implications of the "anytime, anyplace" instrumentality of online education. We close with a series of pedagogical recommendations.
\end{abstract}

Keywords: peer assessment, hybrid format, online education, Canvas LMS 


\section{Introduction}

Research on the design and delivery of online education has focused on a panorama of dimensions, such as learning effectiveness, testing effects, academic honesty, test anxiety, social dynamics, student achievement, and learning strategies. Increasingly, complementary trends in the expanding technological functionality of learning management systems (LMS) along with growing interest in improving the integrity of the performance of online classes, compel evaluating pedagogies once regarded as impractical but now increasingly straightforward.

For example, instructors look to the robust potential of peer assessments to set, support, and sustain a course context that promotes student engagement and learning effectiveness. In principle, by creating systematic opportunities for classmates to assess and constructively criticize each other's works, the peer review process reportedly promotes engagement on a variety of intellectual, social, and operational fronts. Completing the assigned responsibility of formally assessing their classmates' work, an often unprecedented charge, promotes several drivers of student engagement, including motivation, reflection, autonomy, self-efficacy, diplomacy, problem-solving, and responsibility (Boud \& Falchikov, 2007; Stepanyan, Mather, Jones, \& Lusuardi, 2009). Done well, Mulder, Pearce, and Baik (2014) conclude, peer reviews "nurture an impressively wide array of generic skills related to giving and accepting criticism, which are of fundamental importance in any professional workplace."

In principle, elucidations of the theoretical benefits of peer assessment are compelling. However, scant research has looked at how students perceive the opportunity of and then interpret the value of their direct experience with peer assessment over the course of a class (Mulder et al., 2014; Nicol, Thomson, \& Breslin, 2014). Once an understandable gap, current circumstances make it increasingly problematic. Traditionally, administering the peer assessment process within the context of a course, either on-campus or online, without the aid of custom-designed software imposed onerous logistics. Consequently, despite compelling educational, professional, and pedagogical merits, the typical student had few, if any, formal opportunities to review their classmates' work (Lunstrom \& Baker, 2009; Mulder et al., 2014). Now, the progressive sophistication of cloud-based LMSs, by revolutionizing the practicality of real-time peer assessments, support wide-scale use. Indeed, LMSs' improving functionality make it increasingly easier for instructors to administer and students to engage peer assessment procedures.

Commensurately, improving our understanding of the potential for peer assessment procedures to enhance students' engagement promises to bolster the effectiveness of online education. This supposition, of course, presumes that students expect and then experience meaningful utility from participating in the peer review process. Presently, however, empirical research on peer assessment falls short of unequivocally documenting whether students assigned peer review responsibilities anticipate it to be and then conclude it was a worthwhile, productive pedagogy. This paper aims to help fill this gap. 


\section{Setting a Design and Delivery Standard}

Translating the potential of peer reviews into purposeful, productive performance ultimately requires the effective design and efficient delivery of a useful activity (Boud, 2000; Mulder et al., 2014). Expectedly, given the intrinsic ambiguity of the educational process, there is tremendous variance in setting a valid standard to evaluate the usefulness of potential course design and delivery options. Our interest in the performance of the peer review pedagogy in online and hybrid formats made us particularly mindful of the moderators of student learning in online environments. More precisely, after designing and delivering a series of hybrid and online courses, like others, the authors steadily but surely saw the performance implications and social dynamics of how students opted to engage activities, assignments, and assessments (Richardson \& Newby, 2010). Always important to student performance, online education dramatically increases the importance of student engagement (Dixson, 2012; Carr, 2014). Hence, we heed research on student engagement and its assertion that it occurs when "students make a psychological investment in learning. They try hard to learn what school offers. They take pride not simply in earning the formal indicators of success (grades), but in understanding the material and incorporating or internalizing it in their lives" (Newman, 1992). Assessing student engagement, both as a construct and an outcome, allows us to go beyond anecdotes and course grades to gain knowledge about how students go about the process and procedures of learning.

Pressing in any context, we believe engineering student engagement is particularly important in online formats. Research, anchored in traditional, face-to-face, classroom settings, identifies straightforward standards to spur students to engage peer review assignments. Promoting effective learning cycles, whereby students meaningfully engage the class as well as their classmates, calls for catalyzing the social connections that promote interpersonal collaboration (Boud \& Falchikov, 2007). Working interactively enables peers to experience the in situ behavioral gestalt that supports the constructive relationships that influence the effectiveness of peer assessment (Greguras, Robie, \& Born, 2001). Furthermore, productive interactions with peers boost students' diplomatic skills and negotiation competencies. This, in turn, contributes to the collaborative and participatory learning environment that supports effective review processes (Mulder et al., 2014). Empirically, research documents the convergence between the potential and performance of peer review in the bricks-and-mortar classroom (Cartney, 2010; Mulder et al., 2014).

Presently, we cannot say the same with respect to the potential and performance of peer assessment in online environments. The unique milieu of an online class, particularly when framed in terms of orthodox social cognitive or self-determination perspectives, creates situational uncertainties regarding a range of personal and contextual variable (Pekrun, 2006; Artino, 2009). For example, Crews and Butterfield (2014) found that face-to-face interaction significantly affects personal and environmental contextual relationships. If so, for example, then how does the absence of conventionally defined face-time in an online environment affect students' interpretation of the potential and performance of peer assessment opportunities? Consequently, educational constructs, extensively mapped in the bricks and mortar classroom, such as time, place, motivation, and cognitive engagement, presently defy 
straightforward specification in an online setting. Put directly, empirical research on peer assessment falls short of unequivocally documenting whether students who are assigned peer review responsibilities expect it to be and then conclude it was a worthwhile, productive pedagogy. And, absent objective information, we struggle to determine whether peer assessment procedures promote or, quite possibly, discourage student engagement.

\section{Research Questions}

This study helps fill this gap, anchoring its analytics and explanation in terms of evidenced-based procedures administered to undergraduate and graduate students across a series of university-level hybrid and online-only classes. This design allows us to examine two fundamental research questions. First, how does the peer review process influence students' views in terms of the task, procedural, and process aspects of student engagement? Data collected from students prior to and then post-participation in the peer review process supports this analysis. Second, we assess how students' perceptions of the peer review process vary depending on class format or duration. Data from the different course formats-e.g., online and hybrid support this analysis. Combined, these lines of study clarify theoretical aspects and applied implication of the peer review process with respect to promoting student engagement.

\section{Method}

\subsection{Sample}

We designed a quasi-longitudinal, cross-sectional sample based on a series of courses that ran from Spring 2014 through Fall 2014. Over that span, the two authors delivered 8 courses -4 hybrid and 4 completely online courses at a public University in the Mid-Atlantic region. The hybrid courses involved undergraduates, the latter MBAs. The first author taught all hybrid as well as 2 online sections; each of these classes was a survey course of the global business environment. This course is a senior-level requirement for all undergraduate international business majors, an elective for various majors in the University, and, with regards to the graduate population, an elective of the MBA program. The second author taught the remaining 2 online sections. Both were the capstone Corporate Strategy course, a core requirement of the MBA program. Collectively these courses generated our sample of 272 students, 156 of whom took a hybrid course, and 116 of whom took the online-only course.

\subsection{Peer Assessment Procedures}

Logistically, all courses applied the peer assessment function provided by the Canvas LMS (Note 1). We configured this function, on a course by course basis, to assign peer review responsibilities to each student automatically. More precisely, when a student submitted his or her assignment, Canvas randomly generated a list of their assigned reviews and notified the student directly. Students then viewed their classmates' submission via the e-reader, applied a preset, point-and-click rubric, and provided narrative feedback in the Comment Stream. We incorporated a preset rubric given reports that the presence of unambiguous evaluative criteria reduces subjectivity and increases inter-rater agreement (Falchikov \& Goldfinch, 2000). Regarding the rubric, it explicitly followed Bloom's Taxonomy, asking the student to 
evaluate each assigned submission in terms of its performance with regards to its effectiveness in "Remembering, Understanding, Analyzing, Applying, Evaluating, and Creating" elements of the class content (Bloom, Engelhart, Furst, \& Krathwohl, 1956). Each dimension applied a 5-point scale, running from Outstanding, Distinctive, Satisfactory, Deficient, and Missing. The score per dimension ran from a high of 4 (Outstanding) to a low of 0 (Missing). Regarding the Comment Stream, it was purposely open-ended with no preset stipulation of minimal expectations; students were charged with the general task of providing useful feedback to their classmates.

All sampled courses used the Canvas LMS and, hence, applied the same peer assessment procedure. As a rule, students reviewed between 3 and 5 other classmates' submissions on two different assignments: (1) an interim discursive assignment (a conventional specified paper on an aspect of the class content) and (2) a summary creative assignment (a so-called virtual field trip that required the student to develop a series of 7 image-slides along with a 50 word or less narrative explanation per slide that represented the most meaningful ideas they had studied during the course). Each assignment had format regulations regarding its scope and scale. All students in the sampled sections reviewed 3 to 5 submissions of each type of assignment.

We did not formally lecture on the principle of nor instruct the students on the procedure of conducting a peer review. Rather, the students were advised to review online resources, supplied by the instructor through the Canvas LMS, which explain the purpose of the task, elaborate its usefulness, and provide general recommendations on how to complete the assignment. Two reasons motivated this choice. First, online courses differ from conventional, face-to-face counterparts, lacking the platform to engage students personally when profiling an assignment. That is, in a conventional class, one can directly coach students on how to engage the intricacies of an unusual assignment, such as the peer review process. We lacked the same opportunity with respect to the online population. Moreover, both instructors designed their online class with an eye toward encouraging students to self-regulate their learning, incorporating a dynamic lesson plan that transferred considerable course responsibilities to the student. Including a module on how to conduct a peer review ran counter to that orientation. With regards to the hybrid formatted courses, maintaining consistency between that subsample as well as the online subsample led to applying the same procedure.

\subsection{Data}

At the start of each course, all students completed an online survey (hereafter, pretest) regarding their initial expectations of their pending experience with the peer assessment procedure. Then, at the end of the course, they completed an online survey (hereafter, posttest) that asked them about their experience. Items on both the pretest and posttest were derived from relevant literatures and in consultation with representatives of the host University's Center for Teaching and Assessment of Learning. Some questions overlap between the pre-and post-surveys; others, given temporality issues, did not. Survey questions used 5-point Likert-scale, bounded by Strongly Agree and Strongly Disagree. Completing these surveys, 
along with one other on aspects of class design and delivery, earned formal credit (a total of 1 percent of the student's final grade). In addition, we conducted follow-up interviews and discussions with students, both formally and informally, throughout the study. Relatedly, College directed course evaluations generated student commentary, some of which spoke of their judgment of the effectiveness of the peer assessment process.

\subsection{Analysis}

Initial data analyses evaluate the frequency distribution of the responses to the various survey measures. We explore the data beyond the full sample by segmenting the views of online and hybrid subsets. Survey research routinely uses Likert-style questionnaires. Still, debate persists regarding the use of parametric versus nonparametric tools. Review of our survey data did not reveal a systematic pattern of skew, either left or right-hand, for the full set as well as the subsets. Therefore, we use parametric tools, namely the t-test, given its power advantage over nonparametric alternatives when assessing a normal distribution. The pairwise t-test assessed differences in students' views on the pre-test and the post-test, whereas the independent sample t-test was used to examine differences in course format (online vs hybrid).

We regard Time and Place as categorical variables. Time was set by whether the course followed a traditional 14-week semester format versus a 7-week accelerated timeframe. Four of the classes were the former, 4 were accelerated. With respect to Place, the hybrid sections conducted 18 in-class, face-to-face sessions of 75 minutes each. In addition, the hybrid sections used an extensive series of online assignments, activities, and assessments staggered over the course of the 14 week semester. These online activities replaced 8 face-to-face class sessions. The 4 classes taught completely online relied exclusively on electronic contact between students and their classmates as well as with the professor.

\section{Results}

Response rates for the pretest and posttest surveys averaged $99 \%$ across the sampled sections (high of $100 \%$, low of $97 \%$ ). Table 1 reports the results for the research items with regards to student's views on the pretest and posttest. In terms of the pretest, in anticipation of the peer review process, students consistently rated highly nearly all measures. The highest-rated measure on the pretest was a bit of a surprise--nearly $90 \%$ of the sample agreed that "In developing my understanding of the class materials, I expect that completing peer reviews of my classmates' work will be helpful." A corollary measure received strong support: "completing peer reviews will help me to understand what qualifies as outstanding versus poor performance" found agreement from $75 \%$ of the sample. Students regarded various indicators of the potential value of the peer review process positively. Nearly $70 \%$ of the sample expected its benefits to outweigh its demands and $80 \%$ saw the peer review processes providing a useful platform to develop the sorts of competencies sought in the workplace, notably providing and receiving criticism. Most students expected their classmates to do a good job providing them critical and useful feedback. Lastly, just 30 percent of the sample worried that completing their assigned peer reviews would take a lot of time and effort. 
Table 1. Students' view of the peer evaluation process. Pre-and post-test frequencies and tests of mean differences $(\mathrm{N}=272)$

\begin{tabular}{|c|c|c|c|c|c|c|c|c|}
\hline \multirow[b]{2}{*}{ Item } & \multirow[b]{2}{*}{ Source } & \multicolumn{5}{|c|}{ Percent Per Category } & \multirow[b]{2}{*}{$\begin{array}{l}\text { Mean } \\
(5=\text { High, } \\
\text { 1=Low) } \\
\text { /SD }\end{array}$} & \multirow[b]{2}{*}{$\begin{array}{l}\text { Paired } \\
\text { t-test: } \\
\text { t-value/ } \\
\text { p-value }\end{array}$} \\
\hline & & $\begin{array}{l}\text { Strongly } \\
\text { Disagree }\end{array}$ & Disagree & Neutral & Agree & $\begin{array}{l}\text { Strongly } \\
\text { Agree }\end{array}$ & & \\
\hline \multirow{2}{*}{$\begin{array}{l}\text { Overall, I expect that } \\
\text { the benefits of the } \\
\text { peer review process } \\
\text { will outweigh its } \\
\text { demands. }\end{array}$} & Pre-Test & 0 & 7.0 & 23.6 & 49.4 & 19.9 & $3.82 / .83$ & \multirow{2}{*}{$\begin{array}{l}\mathrm{t}=3.364 \\
\mathrm{p}=.001\end{array}$} \\
\hline & Post-Test & 3.2 & 10.3 & 27.0 & 43.7 & 15.9 & $3.59 / .98$ & \\
\hline \multirow{2}{*}{$\begin{array}{l}\text { I'm worried that } \\
\text { completing my } \\
\text { assigned peer } \\
\text { reviews will take a } \\
\text { lot of time and } \\
\text { effort. }\end{array}$} & Pre-Test & 3.7 & 33.2 & 32.8 & 24.7 & 5.5 & $2.95 / .97$ & \multirow{2}{*}{$\begin{array}{l}\mathrm{t}=.323 \\
\mathrm{p}=.747\end{array}$} \\
\hline & Post-Test & 6.3 & 33.3 & 29.4 & 26.6 & 4.4 & $2.89 / 1.01$ & \\
\hline \multirow{2}{*}{$\begin{array}{l}\text { Overall, I believe the } \\
\text { process of peer } \\
\text { reviewing } \\
\text { improve my ability } \\
\text { to accept and give } \\
\text { criticism to my } \\
\text { classmates. }\end{array}$} & Pre-Test & 0.4 & 2.9 & 10.9 & 64.9 & 20.9 & $4.01 / .69$ & \multirow{2}{*}{$\begin{array}{l}\mathrm{t}=4.74 \\
\mathrm{p}=.000\end{array}$} \\
\hline & Post-Test & 3.2 & 7.7 & 19.4 & 53.2 & 16.7 & $3.72 / .94$ & \\
\hline \multirow{2}{*}{$\begin{array}{l}\text { I believe that } \\
\text { formally, reviewing } \\
\text { my peer's work will } \\
\text { provide valuable } \\
\text { experience } \\
\text { preparation for the } \\
\text { workplace. }\end{array}$} & Pre-Test & 0.4 & 2.9 & 18.5 & 53.4 & 24.8 & $3.99 / .77$ & \multirow{2}{*}{$\begin{array}{l}\mathrm{t}=2.83 \\
\mathrm{p}=.005\end{array}$} \\
\hline & Post-Test & 1.4 & 9.0 & 16.7 & 52.7 & 20.3 & $3.81 / .91$ & \\
\hline \multirow{2}{*}{$\begin{array}{l}\text { I expect that my } \\
\text { peers will do a good } \\
\text { job providing me } \\
\text { with critical and } \\
\text { useful feedback. }\end{array}$} & Pre-Test & 0.4 & 5.4 & 22.2 & 57.7 & 14.2 & $3.80 / .76$ & \multirow{2}{*}{$\begin{array}{l}\mathrm{t}=2.95 \\
\mathrm{P}=.004\end{array}$} \\
\hline & Post-Test & 1.2 & 7.5 & 27.8 & 53.6 & 9.9 & $3.64 / .81$ & \\
\hline \multirow{2}{*}{$\begin{array}{lr}\text { I believe } & \text { my } \\
\text { classmates } & \text { will } \\
\text { objectively } & \text { and } \\
\text { fairly review } & \text { my } \\
\text { work. } & \end{array}$} & Pre-Test & 0 & 2.9 & 19.2 & 62.8 & 15.1 & $3.90 / .67$ & \multirow{2}{*}{$\begin{array}{l}t=.609 \\
p=.543\end{array}$} \\
\hline & Post-Test & 1.4 & 4.5 & 18.1 & 57.5 & 18.6 & $3.87 / .81$ & \\
\hline \multirow{2}{*}{$\begin{array}{l}\text { I expect that } \\
\text { completing peer } \\
\text { reviews will help me } \\
\text { to understand what } \\
\text { qualifies as } \\
\text { outstanding versus } \\
\text { poor performance. }\end{array}$} & Pre-Test & 2.4 & 6.6 & 18.6 & 49.1 & 23.4 & $3.84 / .94$ & \multirow{2}{*}{$\begin{array}{l}\mathrm{t}=-1.39 \\
\mathrm{p}=.166\end{array}$} \\
\hline & Post-Test & 0.5 & 5.0 & 13.5 & 50.9 & 30.2 & $4.05 / .82$ & \\
\hline \multirow{2}{*}{$\begin{array}{l}\text { In developing my } \\
\text { understanding of the } \\
\text { class materials, I } \\
\text { expect that } \\
\text { completing peer } \\
\text { reviews of my } \\
\text { classmates' work } \\
\text { will be helpful }\end{array}$} & Pre-Test & 0 & 4.2 & 6.0 & 58.1 & 31.7 & $4.17 / .72$ & \multirow{2}{*}{$\begin{array}{l}\mathrm{t}=4.22 \\
\mathrm{p}=.000\end{array}$} \\
\hline & Post-Test & 2.7 & 13.5 & 8.6 & 46.4 & 28.8 & $3.85 / 1.07$ & \\
\hline
\end{tabular}




\section{Macrothink}

The results of the posttest indicate that for nearly all measures, the average student's views changed, changed for the worse and, in several cases, changed significantly. Notably, after experiencing the peer review process, fewer students saw its benefits outweighing its demands. This indicator's mean rating decreased $6 \%$, falling from 3.82 on the pretest to 3.59 on the posttest; this decrease was highly significant $(\mathrm{p}>.001)$. Mean values for items that measured students' ability to adopt an executive perspective-namely, giving and accepting criticism that is part of parcel of the professional workplace-also declined significantly ( $p>.000$ ) between the pretest to the posttest. Correspondingly, students' expectation of receiving fair and objective criticism from their classmates declined after experiencing the peer assessment process. Table 1 shows that for only one measure did students' agreement increase from the pretest to the posttest. Namely, "I expect that completing peer reviews will help me to understand what qualifies as outstanding versus poor performance" found greater support after students had participated in assessing their peers. In the pretest, 72.5 percent of the sample agreed; in the posttest, 81.1 percent did. This increase was not statistically significant.

Assessing the data in terms of our control variables, time and place, followed the same analytic routine (See Tables $2 \mathrm{a}$ - Pre-test, and $2 \mathrm{~b}$ - Post-test). Frequency analyses indicate negligible differences in the scale and scope of students' views when controlling for time and place. Independent sample T-tests of the mean differences between the online/7-week sessions and the hybrid/full semester sessions confirmed this general tendency. Contrary to expectation, students' perceptions of the peer review process did not differ significantly between online only versus hybrid formatted courses. However, the hybrid/full semester students indicated that the peer review process helped motivate them to take responsibility for their own learning to a significantly greater extent than did students in the accelerated online courses. 
Table 2a. Online vs. hybrid frequencies and tests of mean differences. Students' pre-test view of the peer evaluation process $(\mathrm{N}=272)$

\begin{tabular}{|c|c|c|c|c|c|c|c|c|}
\hline \multirow[b]{2}{*}{ Item } & \multirow[b]{2}{*}{ Source } & \multicolumn{5}{|c|}{ Percent Per Category } & \multirow[b]{2}{*}{$\begin{array}{l}\text { Mean } \\
(5=\text { High, } \\
1=\text { Low }) \\
\text { /SD }\end{array}$} & \multirow[b]{2}{*}{$\begin{array}{l}\text { Paired } \\
\text { t-test: } \\
\text { t-value/p- } \\
\text { value }\end{array}$} \\
\hline & & $\begin{array}{l}\text { Strongly } \\
\text { Disagree }\end{array}$ & Disagree & Neutral & Agree & $\begin{array}{l}\text { Strongly } \\
\text { Agree }\end{array}$ & & \\
\hline \multirow{2}{*}{$\begin{array}{l}\text { Overall, I expect that } \\
\text { the benefits of the } \\
\text { peer review process } \\
\text { will outweigh its } \\
\text { demands. }\end{array}$} & Online & 0 & 7.8 & 22.6 & 47.8 & 21.7 & $3.85 / .86$ & \multirow{2}{*}{$\begin{array}{l}\mathrm{t}=.20 \\
\mathrm{p}=.840\end{array}$} \\
\hline & Hybrid & 0 & 6.4 & 24.4 & 50.6 & 18.6 & $3.81 / .81$ & \\
\hline \multirow{2}{*}{$\begin{array}{l}\text { I'm worried that } \\
\text { completing my } \\
\text { assigned peer reviews } \\
\text { will take a lot of time } \\
\text { and effort. }\end{array}$} & Online & 4.3 & 29.6 & 31.3 & 28.7 & 6.1 & $3.03 / 1.00$ & \multirow{2}{*}{$\begin{array}{l}\mathrm{t}=1.07 \\
\mathrm{p}=.284\end{array}$} \\
\hline & Hybrid & 3.2 & 35.9 & 34.0 & 21.8 & 5.1 & $2.90 / .95$ & \\
\hline \multirow{2}{*}{$\begin{array}{l}\text { Overall, I believe the } \\
\text { process of peer } \\
\text { reviewing } \\
\text { improve my ability to } \\
\text { accept and give } \\
\text { criticism to my } \\
\text { classmates. }\end{array}$} & Online & 0 & 7.2 & 15.7 & 54.2 & 22.9 & $3.93 / .82$ & \multirow{2}{*}{$\begin{array}{l}\mathrm{t}=1.52 \\
\mathrm{p}=.131\end{array}$} \\
\hline & Hybrid & 0.6 & 0.6 & 8.3 & 70.5 & 19.9 & $4.08 / .60$ & \\
\hline \multirow{2}{*}{$\begin{array}{l}\text { I believe that formally } \\
\text { reviewing my peer's } \\
\text { work will provide } \\
\text { valuable experience } \\
\text { and preparation for } \\
\text { the workplace. }\end{array}$} & Online & 1.2 & 6.1 & 25.6 & 39.0 & 28.0 & $3.87 / .94$ & \multirow{2}{*}{$\begin{array}{l}\mathrm{t}=1.65 \\
\mathrm{p}=.101\end{array}$} \\
\hline & Hybrid & 0 & 1.3 & 14.7 & 60.9 & 23.1 & $4.06 / .65$ & \\
\hline \multirow{2}{*}{$\begin{array}{l}\text { I expect that my peers } \\
\text { will do a good job } \\
\text { providing me with } \\
\text { critical and useful } \\
\text { feedback. }\end{array}$} & Online & 0 & 7.2 & 25.3 & 56.6 & 10.8 & $3.71 / .76$ & \multirow{2}{*}{$\begin{array}{l}\mathrm{t}=1.31 \\
\mathrm{p}=.192\end{array}$} \\
\hline & Hybrid & 0.6 & 4.5 & 20.5 & 58.3 & 16.0 & $3.85 / .76$ & \\
\hline \multirow{2}{*}{$\begin{array}{l}\text { I believe my } \\
\text { classmates will } \\
\text { objectively and fairly } \\
\text { review my work. }\end{array}$} & Online & 0 & 3.6 & 26.5 & 55.4 & 14.5 & $3.81 / .72$ & \multirow{2}{*}{$\begin{array}{l}\mathrm{t}=1.50 \\
\mathrm{p}=.137\end{array}$} \\
\hline & Hybrid & 0 & 2.6 & 15.4 & 66.7 & 15.4 & $3.95 / .64$ & \\
\hline \multirow{2}{*}{$\begin{array}{l}\text { I expect that } \\
\text { completing peer } \\
\text { reviews will help me } \\
\text { to understand what } \\
\text { qualifies as } \\
\text { outstanding versus } \\
\text { poor performance. }\end{array}$} & Online & 2.4 & 10.8 & 20.5 & 48.2 & 18.1 & $3.69 / .97$ & \multirow{2}{*}{$\begin{array}{l}\mathrm{t}=-2.18 \\
\mathrm{p}=.031\end{array}$} \\
\hline & Hybrid & 2.4 & 2.4 & 16.7 & 50.0 & 28.6 & $4.00 / .88$ & \\
\hline \multirow{2}{*}{$\begin{array}{l}\text { In developing my } \\
\text { understanding of the } \\
\text { class materials, I } \\
\text { expect that completing } \\
\text { peer reviews of my } \\
\text { classmates' work will } \\
\text { be helpful }\end{array}$} & Online & 0 & 7.2 & 8.4 & 44.6 & 39.8 & $4.17 / .88$ & \multirow{2}{*}{$\begin{array}{l}t=.62 \\
p=.536\end{array}$} \\
\hline & Hybrid & 0 & 1.2 & 3.6 & 71.4 & 23.8 & $4.18 / .54$ & \\
\hline
\end{tabular}


Table 2b. Online vs. Hybrid Frequencies and Tests of Mean Differences. Students' post-test view of the peer evaluation process $(\mathrm{N}=272)$

\begin{tabular}{|c|c|c|c|c|c|c|c|c|}
\hline \multirow[b]{2}{*}{ Item } & \multirow[b]{2}{*}{ Source } & \multicolumn{5}{|c|}{ Percent Per Category } & \multirow[b]{2}{*}{$\begin{array}{l}\text { Mean } \\
(5=\text { High, } \\
\text { 1=Low }) \\
\text { /SD }\end{array}$} & \multirow[b]{2}{*}{$\begin{array}{l}\text { Paired } \\
\text { t-test: } \\
\text { t-value/p } \\
\text {-value }\end{array}$} \\
\hline & & $\begin{array}{l}\text { Strongly } \\
\text { Disagree }\end{array}$ & Disagree & Neutral & Agree & $\begin{array}{l}\text { Strongly } \\
\text { Agree }\end{array}$ & & \\
\hline \multirow{2}{*}{$\begin{array}{l}\text { Overall, I expect that the } \\
\text { benefits of the peer } \\
\text { review process will } \\
\text { outweigh its demands. }\end{array}$} & Online & 3.7 & 12.1 & 26.2 & 37.4 & 20.6 & $3.59 / 1.06$ & \multirow{2}{*}{$\begin{array}{l}\mathrm{t}=.01 \\
\mathrm{p}=.991\end{array}$} \\
\hline & Hybrid & 2.8 & 9.1 & 27.3 & 48.3 & 12.6 & $3.59 / .92$ & \\
\hline \multirow{2}{*}{$\begin{array}{l}\text { I'm worried that } \\
\text { completing my assigned } \\
\text { peer reviews will take a } \\
\text { lot of time and effort. }\end{array}$} & Online & 7.5 & 33.6 & 28.0 & 28.0 & 2.8 & $2.85 / 1.00$ & \multirow{2}{*}{$\begin{array}{l}\mathrm{t}=-.56 \\
\mathrm{p}=.576\end{array}$} \\
\hline & Hybrid & 5.6 & 33.6 & 29.4 & 25.9 & 5.6 & $2.92 / 1.02$ & \\
\hline \multirow{2}{*}{$\begin{array}{l}\text { Overall, I believe the } \\
\text { process of peer reviewing } \\
\text { will improve my ability } \\
\text { to accept and give } \\
\text { criticism to my } \\
\text { classmates. }\end{array}$} & Online & 2.6 & 13.0 & 23.4 & 44.2 & 16.9 & $3.60 / 1.00$ & \multirow{2}{*}{$\begin{array}{l}\mathrm{t}=.1 .41 \\
\mathrm{p}=.162\end{array}$} \\
\hline & Hybrid & 3.5 & 4.9 & 17.5 & 57.3 & 16.8 & $3.79 / .90$ & \\
\hline \multirow{2}{*}{$\begin{array}{l}\text { I believe that formally } \\
\text { reviewing my peer's } \\
\text { work will provide } \\
\text { valuable experience and } \\
\text { preparation for the } \\
\text { workplace. }\end{array}$} & Online & 1.3 & 10.4 & 19.5 & 42.9 & 26.0 & $3.82 / .98$ & \multirow{2}{*}{$\begin{array}{l}\mathrm{t}=.05 \\
\mathrm{p}=.958\end{array}$} \\
\hline & Hybrid & 1.4 & 8.4 & 14.7 & 58.7 & 16.8 & $3.81 / .86$ & \\
\hline \multirow{2}{*}{$\begin{array}{l}\text { I expect that my peers } \\
\text { will do a good job } \\
\text { providing me } \\
\text { critical and } \\
\text { feedback. }\end{array}$} & Online & 1.9 & 9.3 & 26.2 & 47.7 & 15.0 & $3.64 / .91$ & \multirow{2}{*}{$\begin{array}{l}\mathrm{t}=.14 \\
\mathrm{p}=.885\end{array}$} \\
\hline & Hybrid & 0.7 & 6.3 & 28.7 & 58.0 & 6.3 & $3.63 / .73$ & \\
\hline \multirow{2}{*}{$\begin{array}{l}\text { I believe my classmates } \\
\text { will objectively and } \\
\text { fairly review my work. }\end{array}$} & Online & 1.3 & 5.2 & 22.1 & 53.2 & 18.2 & $3.81 / .72$ & \multirow{2}{*}{$\begin{array}{l}\mathrm{t}=-.72 \\
\mathrm{p}=.471\end{array}$} \\
\hline & Hybrid & 1.4 & 4.2 & 16.2 & 59.2 & 19.0 & $3.95 / .64$ & \\
\hline \multirow{2}{*}{$\begin{array}{l}\text { I expect that completing } \\
\text { peer reviews will help } \\
\text { me to understand what } \\
\text { qualifies as outstanding } \\
\text { versus poor performance. }\end{array}$} & Online & 1.3 & 5.2 & 15.6 & 48.1 & 29.9 & $3.69 / .97$ & \multirow{2}{*}{$\begin{array}{l}\mathrm{t}=-.66 \\
\mathrm{p}=.510\end{array}$} \\
\hline & Hybrid & 0 & 4.9 & 12.6 & 52.4 & 30.1 & $4.00 / .88$ & \\
\hline \multirow{2}{*}{$\begin{array}{l}\text { In developing my } \\
\text { understanding of the } \\
\text { class materials, I expect } \\
\text { that completing peer } \\
\text { reviews of my } \\
\text { classmates' work will be } \\
\text { helpful }\end{array}$} & Online & 2.6 & 13.0 & 11.7 & 36.4 & 36.4 & $4.17 / .87$ & \multirow{2}{*}{$\begin{array}{l}\mathrm{t}=.59 \\
\mathrm{p}=.550\end{array}$} \\
\hline & Hybrid & 2.8 & 14.0 & 7.0 & 51.0 & 25.2 & $4.18 / .54$ & \\
\hline
\end{tabular}

\section{Discussion}

Mapping the elements and effectiveness of peer assessment attracts increasing attention. Consistently, studies and surveys highlight the role of students' outlooks, cognitive and 
affective motivations, and expectations as moderators of their engagement with the course. However, evidence-based research on students' views of the potential and performance of peer review lags, thereby hindering our ability to translate the growing volume of anecdotes about students' view of reviewing classmates into systematic knowledge that guides effective course design and delivery. Deficiencies are particularly glaring, given the fast-developing capabilities of leading LMSs, with respect to the context of hybrid and online education.

Our results help resolve some of these concerns, especially with respect to the issue of student engagement. Again, the increasingly impersonal teacher-student relationship found in online and hybrid courses challenges conventional notions of engaging a student in a productive and meaningful learning experience. Given online content's lack of the persuasive merits of professorial charisma, motivating students to make a "psychological investment in learning" is a daunting proposition. In online classes, efforts to mimic the social processes that mark the face-to-face classroom, via cyber-based relationship-building strategies, struggle (Nicol et. al., 2014). Furthermore, geo-dispersion fosters benign anonymity, both among students as well as with the instructor (Santana, 2014). Similarly, asynchronous workflow makes it difficult to promote contact via real-time collaboration. The fundamentally different outlooks at play in a brick and mortar class versus an online course complicate both. Whereas face-to-face interactions anchor the value of classroom settings, online instructors must look to promote student engagement with a class design structure that precisely specifies activities, assignments, and assessments without unduly sacrificing flexibility, organization, and clear expectations (Crews \& Butterfield, 2014; Dixson, 2012). This literature suggests that encouraging students in an online environment to engage the class, as well as each other, fundamentally depends on the design and delivery of the course content. Done well, students engage and make a psychological investment in learning. Done poorly, students disengage, drop-off, and, in extreme cases, dropout.

In principle, our data indicate that the sampled students agreed that the peer review process provided a robust method to improve engagement. That is, students consistently recognized the potential value of the peer review process to making the class a more meaningful experience. Across the sampled sections, which spanned graduate and undergraduates, traditional versus accelerated semesters, as well as differentiated course content, students consistently affirmed the value of the opportunity to participate in peer assessment. On this theme, Eccles and Wigfield (1995) define task value as "the value a task acquires because it is instrumental in reaching a variety of long and short-range goals." Corresponding measures in this study indicate that the sampled students recognize the intrinsic task value of the peer review process; measures asking about professional benefits, workflow requirements, and academic insights consistently score highly on the pre-and the posttest. With that in mind, if we accept the proposition that these outlooks are markers for student engagement, then it seems quite plausible that the peer review opportunity positioned students to benefit from the motivational, reflective, self-efficacy, autonomy, and self-regulated attributes of engagement (Boud \& Falchikov, 2007; Richardson \& Newby, 2010). 


\subsection{Mismatch: Expectations vs. Experience}

Given the proceeding result, how then might we interpret the drop in students' perception of the value of the peer review process-again, recall the slight but systematic decline in mean values on virtually all measures between the pretest and posttest. First and foremost, this result has broad precedent. A similarly designed investigation by Mulder et al. (2014) reports that "prior to engaging in peer review, students had remarkably high expectation of both the process and the competence of their peers as reviewers...However, a modest overall downward shift and positive perception was observed following peer review." In many ways, our results echo the reported mismatch between expectations and outcomes. Mulder et al. (2014) struggling to pinpoint an explanation, recommend further research to isolate these issues and untangle the relationship.

Our results, along with an ongoing series of conversations with students and colleagues, point to a likely explanation. Operationally, recall that we relied upon the Canvas LMS to organize and administer the peer evaluation process. Overall, the functionality of this procedure is markedly robust, supporting efficient administration for the instructor as well as straightforward engagement for the student. However, the Canvas procedure suffers a key limitation - one does not have the option to make the peer review process anonymous. That is, all peer reviewers know the identity of the students whose work they are reviewing. Likewise, all students know who has reviewed their work.

The lack of anonymity enacts a potentially problematic situation. Research reports that interpersonal variables, in the absence of anonymity, likely moderate how students apply the peer review procedure (Van Gennip, Segers, \& Tillema, 2009; Stepanyan et al., 2009). More precisely, factors such as peer pressure and fear of disapproval when assigning low scores can affect the outcomes of classmates' respective assessments. Others point to various social dynamics as likely influencing students' objectivity in assessing the quality of their classmates' work (Panadero et al., 2013; Boud, 2000). Effectively, the implicit pressure to praise mediocrity, or in the least, avoid criticizing it, may, in turn, result in peer assessments that led some students to question the value, if not the legitimacy, of the peer review process. So, for example, the highly significant drop, from the pretest and posttest, in the mean value of items such as "In developing my understanding of the class materials, I expect that completing peer reviews of my classmates' work will be helpful" or "Overall, I believe the process of peer reviewing will improve my ability to accept and give criticism to my classmates," arguably speaks to some students' sensitivity to this situation. The authors are conducting further research to unravel this relationship, questioning students about the importance of anonymity as well as developing measures to gauge the objectivity of the commentary provided from a peer reviewer to a classmate.

\subsection{Time and Place}

Interestingly, and quite honestly, surprisingly, neither time nor place influenced students' views of the peer assessment process. In theory, time and place moderate patterns of student engagement, a key precursor of effective peer assessment (Carr, 2014; Nicol et. al., 2014). Orthodox face-to-face classes involve classmates progressively developing social routines 
and interpersonal relations that anchor effective peer engagement. Social processes set and sustain the intricate relationship between emotion and cognition in the processes commonly linked to learning (Pekrun, 2006; Artino, 2009). Crews and Butterfield (2014), for example, report that students saw the most positive impact of face-to-face learning in terms of this facilitation of direct interaction in the context of lectures, discussions, and in-class group activities. Enabling students to find common ground with ostensible strangers within a face-to-face class establishes the basis for the confident interactions that support a student's capacity to assess his or her peers.

Furthermore, the face-to-face class setting requires students attend lectures or participate in class-based activities, thereby benefiting from the interaction provided by the physical learning environment, the classroom milieu, and the ethos of the wider University. Schutz, Hong, Cross, and Osbon (2006), for example, linked students' emotional experiences to person-environmental transactions that take place within those sorts of settings, particularly those that emerge in the scripted structure of a classroom. Relatedly, social impact theory suggests that the effects of interpersonal variables should prove stronger in face-to-face classroom settings than in an online course given that that social influences, notably peer pressure, increase when others are physically proximate (Latane, 1981). Pope (2005) and Stepanyan et al. (2009) document this effect, finding that students in face-to-face classroom settings typically feel uncomfortable and experience stress when publicly evaluating their peers.

In contrast, person-environment transaction in an online class differs dramatically. The defining "anytime, anyplace" instrumentality of an online class lets students engage a course and classmates wherever, wherever, and often, in whatever format, they prefer. Relatedly, classes delivered on-campus, either over a quarter or semester, run from 10 to 16 weeks, and span discrete sessions of sustained socialization. In contrast, it is not unusual for an online class to run, from start to finish, just 4 to 7 weeks, during which students will never "meet," conventionally defined, a classmate. In cases where paths cross, most, if not all, do so via the Internet.

Despite the suggestion that time and place should matter, our results indicate otherwise. Searching for precedent for this finding finds little. Tangential topics cover a range of issues, such as lecture length, traditional versus nontraditional students, course organization, or instructor enthusiasm and expertise. We suspect larger trends are afoot. Consider that in 2010, $33 \%$ of US college students enrolled in at least one online class. Presently, more than half of all students in higher education have taken at least one online course. By 2020, forecasts call for roughly $75 \%$ of all college students to do so (Allen \& Seaman, 2014). The increasing exposure and, presumably, increasingly sophisticated familiarity with online education platforms progressively socializes students to accept, if not prefer, self-direction in learning (Brock, 2015).

Indeed, just as online education has reset the boundaries between learners and teachers, by weakening the centralization of expertise and the distribution of subject-matter authority, so too has it reset the boundaries between students and their class, as the design logic of 
"anytime, anyplace" engagement fortifies their direct control of the course (Ponti, 2014; Brock, 2015). Essentially, students are increasingly empowered self-directed learners who, when given the opportunity to self-regulate their engagement of an LMS-centric course, no longer differentiate that engagement in terms of the duration or format of the course. Furthermore, the intrinsic design and delivery structure of an online course demands that students take "responsibility for directing their own learning, time management, keeping up with the class, completing the work on time and being active contributors to instruction" (Hung, Chou, Chen, \& Own, 2010). Fundamentally, shifting from a teacher- to student-centric pedagogy requires higher conscientiousness and sustained self-discipline from a student in self-regulating motivation and goal achievement (Maehr, 1989; Brock, 2015). Moreover, all courses sampled in this study relied upon the Canvas LMS; this choice resulted in designing explicitly stipulated activities, assignments, and assessments in order to systematize the workflow. The imperatives of effective online course design, within the precise context of an LMS, inevitably expand the scale and scope of a student's control of the learning process relative to that of the instructor (Candy, 1991; Brock, 2015). Essentially, our results suggest time and place no longer matter because the "anytime, anyplace" instrumentality of online education makes time and place no longer matter in the context of emergent modes of online education.

\section{Conclusion}

This research evaluates how students anticipate the opportunity and then interpret their experience of the potentially powerful pedagogy of peer assessment in an online environment. Our results, we believe, better inform educational professionals on how to improve the design and delivery of assignments, activities, and assessments in ways that spur and sustain student engagement in an online environment. Fundamentally, we hold that it is the mission of all programs and instructors to design and deliver a range of activities, assignments, and assessments that promote student engagement. Compelling in any context, it is especially so in the online environment. The orthodox dyadic relationship between student and teacher, performed within the scripted environment of a face-to-face, bricks and mortar classroom, provides multiple methods to motivate student engagement. Online, these methods are lost, replaced by the benign impersonality of electronic milieus that, if not challenged, will confound and quite possibly corrupt students' incentive to "learn to learn" (Corno \& Mandinach, 1983). Preempting this threat calls for designing and delivering online courses explicitly geared toward promoting student engagement.

With that in mind, the general theme of our results supports the value of peer review processes and highlights a means to improve its effectiveness. Regarding the former, the vast majority of our sample recognized and then confirmed the value of peer assessment across a range of markers of student engagement. In our sample, most students acknowledged the positive potential and useful performance of the peer review process in helping to understand what qualifies as outstanding versus poor performance. Absent concerted effort, students rarely see real-time examples of excellence as well as failure. The peer review process, by cracking open the black box of examples and standards, provided an effective means to improve the transparency of performance standards and evaluation. 
Although students' view of the value of peer evaluations declined between the pretest and the posttest, it is important to note the strength of student agreement in absolute as well as relative terms. Put differently, on average, for the individual student who questioned the value of the process, three others confirmed it. Looking forward, improving the usefulness of the peer evaluation to the ' 3 ,' as well as demonstrating it to the skeptic, has a straightforward solution. Conversations with students indicate that making assessments anonymous would inspire greater objectivity and, presumably, greater value. To that end, growing research suggests that anonymity might offer a solution for the possible negative impact of problematic interpersonal variables on the perceived utility of peer assessment. Ainsworth et al. (2011) and Howard, Barrett, and Frick (2010) found that anonymity, in terms of giving feedback in the context of an asynchronous web forum, made students approximately five times more likely to provide substantively critical feedback than those whose identities were known to the recipients. Similarly, Vanderhoven, Raes, Montrieux, Rotsaert, and Schellens (2015) "found that pupils felt more positive towards peer assessment and experienced less peer pressure and fear of disapproval when scores were given anonymously using CRT."

On a practical basis, student learning is influenced, positively as well as negatively, by the design and delivery of activities, assignments, and assessments. Our findings, we believe, provide useful guidance to instructors in their consideration of incorporating peer evaluation processes into their course. Operationally, our profile of the strengths and weaknesses of the peer review process delivered via the Canvas LMS highlights its remarkable administrative ease. But, our results also point to a particularly problematic limitation, namely the issue of non-anonymity. Developing a workaround, in the event that Canvas does not offer that option, would improve the effectiveness of the peer review process to set and sustain a higher order level of student engagement. Absent that feature, our results caution instructors to anticipate a likely mismatch between students' view of the potential and then performance of the peer review process.

\section{Future Research}

Improving our understanding calls for future research to model and assess factors and relationships that elaborate the demographic and self-reported data explored here. Potentially useful directions include developing teaching strategies or learning systems to manage the interpersonal behaviors that likely moderate non-anonymous peer evaluation process. Similarly, our interesting findings on the irrelevance of time and place endorse evaluating the fit of current course designs, both online as well as hybrid, with an eye toward the "anyplace, anytime" dynamic of self-directed learning and its implication to student engagement.

\section{Acknowledgements}

This study was funded by the Academic Partnerships Research Grant Program in their ongoing support of research on the impact and effectiveness of online learning.

\section{References}

Ainsworth, S., Gelmini-Hornsby, G., Threapleton, K., Crook, C., O’Malley, C., \& Buda, M. (2011). Anonymity in classroom voting and debating. Learning and Instruction, 21(3), 
365-378. http://dx.doi.org/10.1016/j.learninstruc.2010.05.001

Allen, I. E., \& Seaman, J. (2014). Grade change: Tracking online education in the United States, 2013 (Vol. 3, No. 5). Babson Survey Research Group and Quahog Research Group, LLC.

Artino, A. R. (2009). Online learning: Are subjective perceptions of instructional context related to academic success? The Internet and Higher Education, 12(3), 117-125. http://dx.doi.org/10.1016/j.iheduc.2009.07.003

Boud, D. (2000). Sustainable assessment: Rethinking assessment for the learning society. Studies in Continuing Education, 22(2), 151-168. http://dx.doi.org/10.1080/713695728

Boud, D., \& Falchikov, N. (Eds.). (2007). Rethinking assessment in higher education: Learning for the longer term. Routledge.

Brock, S. E. (2015). Learning and Transformation. Exploring Learning \& Teaching in Higher Education (pp. 233-250). Springer Berlin Heidelberg. http://dx.doi.org/10.1007/978-3-642-55352-3_10

Candy, P. C. (1991). Self-direction for Lifelong Learning. San Francisco: Jossey-Bass.

Carr, M. (2014). The Online University Classroom: One Perspective for Effective Student Engagement and Teaching in an Online Environment. The Journal of Effective Teaching, 99.

Cartney, P. (2010). Exploring the use of peer assessment as a vehicle for closing the gap between feedback given and feedback used. Assessment \& Evaluation in Higher Education, 35(5), 551-564. http://dx.doi.org/10.1080/02602931003632381

Corno, L., \& Mandinach, E. B. (1983). The role of cognitive engagement in classroom learning and motivation. Educational Psychologist, $18(2), \quad 88-108$. http://dx.doi.org/10.1080/00461528309529266

Crews, T., \& Butterfield, J. B. (2014). Data for Flipped Classroom Design: Using Student Feedback to Identify the Best Components from Online and Face-to-Face Classes. Higher Education Studies, 4(3), 38. http://dx.doi.org/10.5539/hes.v4n3p38

Dixson, M. D. (2012). Creating effective student engagement in online courses: What do students find engaging? Journal of the Scholarship of Teaching and Learning, 10(2), 1-13.

Eccles, J. S., \& Wigfield, A. (1995). In the mind of the achiever: The structure of adolescents' academic achievement related-beliefs and self-perceptions. Personality and Social Psychology Bulletin, 21(3), 215-225. http://dx.doi.org/10.1177/0146167295213003

Falchikov, N. (2007). The place of peers in learning and assessment. Rethinking assessment in higher education: Learning for the Longer Term (pp. 128-143).

Falchikov, N., \& Goldfinch, J. (2000). Student peer assessment in higher education: A meta-analysis comparing peer and teacher marks. Review of Educational Research, 70(3), 287-322. http://dx.doi.org/10.3102/00346543070003287 
Howard, C. D., Barrett, A. F., \& Frick, T. W. (2010). Anonymity to promote peer feedback: Pre-service teachers' comments in asynchronous computer-mediated communication. Journal of Educational Computing Research, 43(1), 89-112. http://dx.doi.org/10.2190/EC.43.1.f

Hung, M. L., Chou, C., Chen, C. H., \& Own, Z. Y. (2010). Learner readiness for online learning: Scale development and student perceptions. Computers \& Education, 55(3), 1080-1090. http://dx.doi.org/10.1016/j.compedu.2010.05.004

Latane, B. (1981). The psychology of social impact. American Psychologist, 36(4), 343. http://dx.doi.org/10.1037/0003-066X.36.4.343

Liu, N. F., \& Carless, D. (2006). Peer feedback: The learning element of peer assessment. Teaching in Higher Education, 11(3), 279-290. http://dx.doi.org/10.1080/13562510600680582

Maehr, M. L. (1989). Thoughts about motivation. Research on motivation in education: Goals and cognitions, 3(1), 299-315.

Mulder, R. A., Pearce, J. M., \& Baik, C. (2014). Peer review in higher education: Student perceptions before and after participation. Active Learning in Higher Education, 1469787414527391. http://dx.doi.org/10.1177/1469787414527391

Newmann, F. (1992) Student Engagement and Achievement in American Secondary Schools. Teachers College Press. pp. 2-3.

Nicol, D., Thomson, A., \& Breslin, C. (2014). Rethinking feedback practices in higher education: a peer review perspective. Assessment \& Evaluation in Higher Education, 39(1), 102-122. http://dx.doi.org/10.1080/02602938.2013.795518

Panadero, E., Romero, M., \& Strijbos, J. W. (2013). The impact of a rubric and friendship on peer assessment. Studies in Educational Evaluation, 39(4), 195-203. http://dx.doi.org/10.1016/j.stueduc.2013.10.005

Pekrun, R. (2006). The control-value theory of achievement emotions: Assumptions, corollaries, and implications for educational research and practice. Educational Psychology Review, 18(4), 315-341. http://dx.doi.org/10.1007/s10648-006-9029-9

Ponti, M. (2014). Self-directed learning and guidance in non-formal open courses. Learning, Media and Technology, 39(2), 154-168. http://dx.doi.org/10.1080/17439884.2013.799073

Pope, N. K. L. (2005). The impact of stress in self-and peer assessment. Assessment \& Evaluation in Higher Education, 30(1), 51-63. http://dx.doi.org/10.1080/0260293042003243896

Richardson, J. C., \& Newby, T. (2006). The role of students' cognitive engagement in online learning. The American Journal of Distance Education, 20(1), 23-37. http://dx.doi.org/10.1207/s15389286ajde2001_3

Santana, A. D. (2014). Virtuous or vitriolic: The effect of anonymity on civility in online newspaper reader comment boards. Journalism Practice, 8(1), 18-33. http://dx.doi.org/10.1080/17512786.2013.813194 


\section{Macrothink}

Schutz, P. A., Hong, J. Y., Cross, D. I., \& Osbon, J. N. (2006). Reflections on investigating emotion in educational activity settings. Educational Psychology Review, 18(4), 343-360. http://dx.doi.org/10.1007/s10648-006-9030-3

Stepanyan, K., Mather, R., Jones, H., \& Lusuardi, C. (2009). Student engagement with peer assessment: A review of pedagogical design and technologies. Advances in Web Based Learning - ICWL 2009 (pp. 367-375). Springer Berlin Heidelberg. http://dx.doi.org/10.1007/978-3-642-03426-8_44

Van den Berg, I., Admiraal, W. \& Pilot, A. (2006). Design principles and outcomes of peer assessment in higher education. Studies in Higher Education, 31(3), 341-356. http://dx.doi.org/10.1080/03075070600680836

Van Gennip, N. A., Segers, M. S., \& Tillema, H. H. (2009). Peer assessment for learning from a social perspective: The influence of interpersonal variables and structural features. Educational Research Review, 4(1), 41-54. http://dx.doi.org/10.1016/j.edurev.2008.11.002

Vanderhoven, E., Raes, A., Montrieux, H., Rotsaert, T., \& Schellens, T. (2015). What if pupils can assess their peers anonymously? A quasi-experimental study. Computers \& Education, 81, 123-132. http://dx.doi.org/10.1016/j.compedu.2014.10.001

\section{Notes}

Note 1. The Canvas LMS is a cloud-native software package provided by Instructure, an educational technology company. See http://www.canvaslms.com/higher-education for a fuller profile.

\section{Copyright Disclaimer}

Copyright for this article is retained by the author(s), with first publication rights granted to the journal.

This is an open-access article distributed under the terms and conditions of the Creative Commons Attribution license (http://creativecommons.org/licenses/by/3.0/). 